\title{
Fenton's Oxidation of Personal Care Product (PCP) Wastewater: A Kinetic Study and the Effects of System Parameters
}

\author{
Lieke Riadi ${ }^{1,2^{*}}$, Alan Darmasaputra Tanuwijaya ${ }^{1}$, Ricky Richard Je ${ }^{1}$, Ali Altway ${ }^{3}$ \\ ${ }^{1}$ Chemical Engineering Department, University of Surabaya, Jl. Raya Kalirungkut, Surabaya 60292, \\ Indonesia \\ ${ }^{2}$ Center for Environmental and Renewable Energy Studies, University of Surabaya, Jl. Raya Kalirungkut, \\ Surabaya 60292, Indonesia \\ ${ }^{3}$ Chemical Engineering Department, Sepuluh Nopember Institut of Technology, Jl. Raya ITS, Keputih, \\ Sukolilo, Surabaya 60111, Indonesia
}

\begin{abstract}
Personal care products (PCPs) are considered an emerging class of pollutants, and PCP wastewater is classified as hazardous because it contains organic compounds, which are linked to high chemical oxygen demand (COD) concentrations. PCP wastewater is dangerous when discharged into rivers without treatment, which entails oxidizing complex organic compounds into simpler compounds using advanced oxidation technology (AOT). Fenton's reagent is composed of $\mathrm{Fe}^{2+}$ and $\mathrm{H}_{2} \mathrm{O}_{2}$ and can oxidize organic compounds, thus reducing COD concentrations. This study aims to determine the effectiveness of the AOT method by calculating COD removal in wastewater; analyze the effect of the $\mathrm{Fe}^{2+} / \mathrm{H}_{2} \mathrm{O}_{2}$ ratio, $\mathrm{H}_{2} \mathrm{O}_{2}$ concentration, and system $\mathrm{pH}$; develop a kinetics model of COD reduction; and analyze the cost of PCP wastewater treatment. The parameters used in the study are $\mathrm{Fe}^{2+} / \mathrm{H}_{2} \mathrm{O}_{2}$ ratio, $\mathrm{H}_{2} \mathrm{O}_{2}$ concentration, and $\mathrm{pH}$. The results of this study show that the highest level of COD removal was $88.59 \%$ at a $\mathrm{Fe}^{2+} / \mathrm{H}_{2} \mathrm{O}_{2}$ ratio of $9 \% \mathrm{w} / \mathrm{w}, \mathrm{a} \mathrm{H}_{2} \mathrm{O}_{2}$ concentration of six times the COD concentration, and a $\mathrm{pH}$ value of 3 . The reaction followed pseudo-first-order reaction kinetics, and the reaction rate constant was $0.021 \mathrm{~min}^{-1}$. At a flow rate of $15 \mathrm{~m}^{3} / \mathrm{day}$, which is applicable in an industrial site, the required reactor volume in a continuous system is less than that for a batch system. The required reactor volume for a plug flow reactor and a batch reactor are $1.625 \mathrm{~m}^{3}$ and $2.25 \mathrm{~m}^{3}$, respectively. The estimated cost to treat 1 liter of wastewater is IDR 1,385.
\end{abstract}

Keywords: COD; Fenton; Operation cost; PCP wastewater

\section{Introduction}

Personal care products (PCPs) include antimicrobials, cosmetics, body disinfectants, and other products applied on human skin. An increase in PCP use will increase the discharge of PCP wastewater, as PCP waste usually comes from human excreta (sewage), wrongful disposal, leaching from landfill, drain water, and industrial waste (Archer et al., 2017). PCP waste is categorized as a micropollutant, and each PCP contains various organic compounds. The organic compound concentration in PCP wastewater is usually determined using the chemical oxygen demand (COD) concentration.

PCP waste has recently been detected in drinking water sources at concentrations of 1 $\mathrm{ng} / \mathrm{kg}$ to $1 \mathrm{mg} / \mathrm{kg}$ of drinking water (Suanon et al., 2017). PCP waste is toxic and dangerous

${ }^{*}$ Corresponding author's email: lieke@staff.ubaya.ac.id, Tel.: +62-31-2981158; Fax: +62-31-2981178 doi: 10.14716/ijtech.v12i2.4045 
to humans, causing dysfunction in the endocrine and hormone systems (Archer et al., 2017). Our study investigates PCP wastewater from a pharmaceutical and cosmetic factory in East Java, Indonesia.

Due to its toxicity, PCP wastewater needs to be treated to reduce its COD content to a specific level $(<150 \mathrm{ppm})$ at which it is safe for discharge and to comply with the regulations of the East Java regional Province (No. 72, year 2013).

The method of PCP wastewater treatment impacts the effectiveness of the COD degradation. Some experiments have been carried out to study conventional PCP wastewater treatment methods, i.e., disinfection and biodegradation. Previous studies have treated PCP wastewater using physical-chemical processes and then a biological process, which eventually involved a disinfection treatment using chlorine (Narumiya et al., 2013). Another study was conducted using Eichhornia crassipe and Pistia stratiotes, which are aquatic plants used as pollutant uptake plants and for biosorption in biological methods (Lin and Li., 2015). There also is an anaerob sludge study that used nanoscale zero valent iron (nZVI) synthetics and commercial iron powder (IP) at mesophilic conditions $\left(37 \pm 1^{\circ} \mathrm{C}\right)$ (Suanon et al., 2017). However, the COD degradation efficiency achieved in those studies is less than 50\%, and the processes are time consuming. The application of advanced oxidation technology (AOT) methods in wastewater treatment involves the use of chemical substances as oxidizing agents to degrade organic compounds in wastewater, and it replaces conventional methods (Kanhaiya and Anurag, 2017). Some AOT methods have been implemented in several studies, e.g., treatment of tofu wastewater using combined ozonation and adsorption (Karamah et al., 2019), and a combined electrocoagulation and photocatalysis treatment applied to batik wastewater-which is difficult to employ on a large scale (Sharfan et al., 2018). There is also a degradation study on PCP compounds such as carbamazepine, clofibric acid, and triclosan (commonly found in freshwater sources) using an AOT method (Khraisheh et al., 2013), in which granular activated carbon (GAC), $\mathrm{TiO}_{2}$-coconut shell powder (TCNSP), and UV light were used to degrade PCP compounds. This method can reduce $99 \%$ of the compounds, but there is currently no study on the economic ramifications. Fenton's reagent is one of the reagents that can be used in the AOT method, has recently been used because it is environmentally friendly. Fenton's reagent is made with hydrogen peroxide $\left(\mathrm{H}_{2} \mathrm{O}_{2}\right)$ as an oxidizing agent and ferro(II) ion $\left(\mathrm{Fe}^{2+}\right)$ as a catalyst. Some studies have used Fenton's reagent to reduce hospital waste, azo dye Orange G (OG) waste, and papercraft waste in wastewater. Fenton's reagent can degrade 70-99\% of the initial organic compounds, and the reaction is faster and more economical than any other chemical treatment (Munoz et al., 2016; Kanhaiya and Anurag, 2017; Park et al., 2017). We degraded PCP wastewater from a pharmaceutical factory in East Java using Fenton's reagent in batch mode, which has not previously been studied. Fenton's process is more readily implemented because it is much cheaper and easier to perform than other advanced oxidation processes (AOPs), e.g., $\mathrm{O}_{3} / \mathrm{H}_{2} \mathrm{O}_{2}$. Fenton's process can be carried out at room temperature and atmospheric pressure. The required reagents are readily available, easy to store and handle safely, and environmentally friendly (Pignatello et al., 2006). Therefore, the primary aim of this study is the degradation of PCP wastewater using Fenton's oxidation. The effects of various process parameters, such as the initial concentration of hydrogen peroxide $\left(\mathrm{H}_{2} \mathrm{O}_{2}\right)$, the $\mathrm{Fe}^{2+} / \mathrm{H}_{2} \mathrm{O}_{2}$ ratio, and the system $\mathrm{pH}$, were studied to obtain the optimal parameters for the degradation process. A kinetics model was also developed based on the optimal system parameters obtained from the study, and a comparison of the reactor volumes used in batch and continuous systems is also discussed. Both plug flow and mixed flow reactors, which are cheaper than batch reactors, can be employed on the site. A plug flow reactor (PFR) requires a smaller reactor size than a mixed 
flow reactor (MFR) and batch reactor and has fewer side reactions because the residence time is uniform.

\section{Methods}

\subsection{Materials}

PCP wastewater was collected from a local pharmaceutical and cosmetics factory in East Java. Other chemical materials: $\mathrm{FeSO}_{4} .7 \mathrm{H}_{2} \mathrm{O}, \mathrm{H}_{2} \mathrm{O}_{2} 30 \%, \mathrm{H}_{2} \mathrm{SO}_{4}(98 \% \mathrm{v} / \mathrm{v}), \mathrm{K}_{2} \mathrm{Cr}_{2} \mathrm{O}_{7}$, $\mathrm{NaOH}, \mathrm{KMnO}_{4}, \mathrm{HgSO}_{4}$, and $\mathrm{AgSO}_{4}$, were analytical grade and obtained from Merck.

\subsection{Characterization and Pretreatment of PCP Wastewater}

Characterization of the PCP wastewater was performed to check the initial value for total suspended solid (TSS), COD, biological oxygen demand (BOD), and pH. Pretreatment is required if the initial TSS value is greater than $75 \mathrm{ppm}$ to enable the Fenton's reagent to react effectively without interference from suspended solid particles.

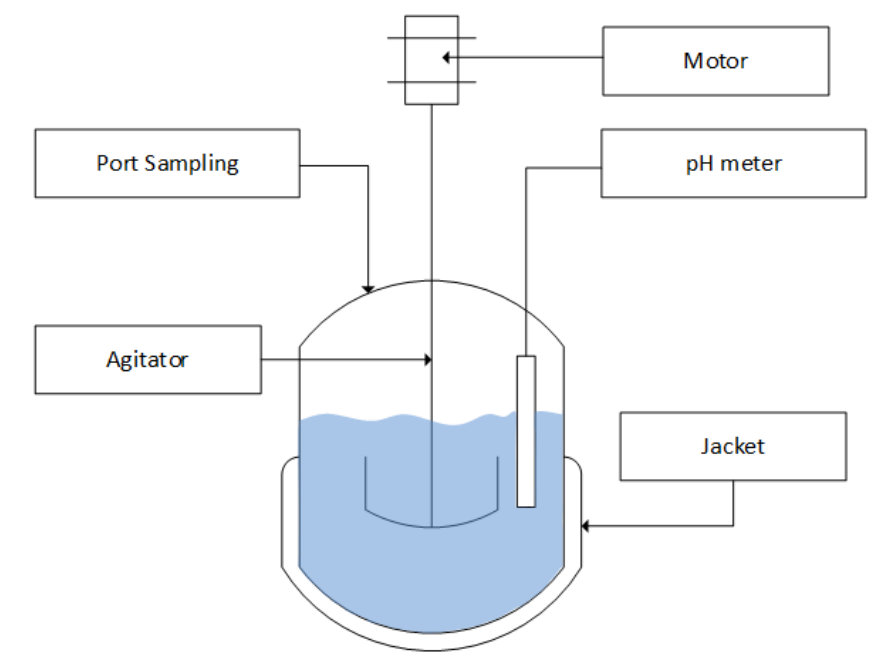

Figure 1 Batch reactor setup

\subsection{PCP Wastewater Degradation using Fenton's Reagent}

Figure 1 shows the experimental setup for the study at room temperature and atmospheric pressure. The working volume of the one liter batch reactor used in this study is $800 \mathrm{~mL}$, comprising $750 \mathrm{~mL}$ of PCP wastewater and $50 \mathrm{~mL}$ of Fenton's reagent. The Fenton's reagent was made from $\mathrm{FeSO}_{4} .7 \mathrm{H}_{2} \mathrm{O}$ and $\mathrm{H}_{2} \mathrm{O}_{2}$, with the $\mathrm{H}_{2} \mathrm{O}_{2}$ as the source of hydroxyl radicals and $\mathrm{Fe}^{2+}$ as the reaction catalyst. The parameters used in this study were a $\mathrm{H}_{2} \mathrm{O}_{2}$ concentration of four, five, and six times the COD concentration; a Fe ${ }^{2+} / \mathrm{H}_{2} \mathrm{O}_{2}$ ratio of $3 \%, 6 \%$, and $9 \% \mathrm{w} / \mathrm{w}$; and an initial $\mathrm{pH}$ value of 2,3 , and 4 . The agitation applied was 200 $\mathrm{rpm}$. The reaction lasted for two hours, and samples were taken every 10 mins to analyze the $\mathrm{pH}, \mathrm{H}_{2} \mathrm{O}_{2}$, and COD concentrations.

\subsection{Assays}

The COD was measured using a closed reflux colorimetric method, the TSS was analyzed using the dried method, and the BOD was analyzed via a 5-day incubation at 20 ${ }^{\circ} \mathrm{C}$. All assays were performed based on the American Public Health Association (APHA) method (APHA,1998). Hydrogen peroxide was analyzed using the titration method with potassium permanganate (Huckaba and Keyes, 1948).

\section{Results and Discussion}

\subsection{Pretreatment of PCP Wastewater}


Wastewater was collected and analyzed to obtain the values of some parameters. The characteristics of the PCP wastewater are presented in Table 1.

Table 1 Wastewater characteristics

\begin{tabular}{ccc}
\hline Parameter & Value & Unit \\
\hline COD & 1.054 & $\mathrm{ppm}$ \\
$\mathrm{pH}$ & 8.5 & $\mathrm{~N} / \mathrm{A}$ \\
Total suspended solid (TSS) & 14 & $\mathrm{ppm}$ \\
Biological oxygen demand (BOD) & 320 & $\mathrm{ppm}$ \\
\hline
\end{tabular}

\subsection{Degradation of PCP Wastewater using Fenton's Reagent}

Fenton's reaction produces highly reactive hydroxyl radicals, which are effective in degrading organic contaminants. The hydroxyl radicals attack organic contaminants present in the wastewater, yielding oxidized products through intermediates (Babuponnusami and Muthukumar, 2014). The effectiveness of hydroxyl radicals in degrading organic contaminants has also been emphasized in a study on phenol degradation in an electrolysis reactor in the presence of $\mathrm{Fe}^{2+}$ (Saksono et al., 2015).

\subsubsection{Effect of the $\mathrm{Fe}^{2+} / \mathrm{H}_{2} \mathrm{O}_{2}$ ratio on COD removal efficiency}

The iron ion $\left(\mathrm{Fe}^{2+}\right)$ is crucial for the generation of $\mathrm{OH}^{x}$ (hydroxyl radical), as expressed in Equation 1 (Gümüs and Akbal, 2016).

$$
\mathrm{H}_{2} \mathrm{O}_{2}+\mathrm{Fe}^{2+} \rightleftharpoons \mathrm{Fe}^{3+}+\mathrm{OH}^{-}+\mathrm{OH}^{*}
$$

To investigate the effect of the $\mathrm{Fe} 2+/ \mathrm{H}_{2} \mathrm{O}_{2}$ ratio on the $\mathrm{COD}$ removal efficiency, the experimental condition was set to various $\mathrm{Fe}^{2+} / \mathrm{H}_{2} \mathrm{O}_{2}$ concentration ratios: $3 \%, 6 \%$, and 9\% $\mathrm{w} / \mathrm{w}$, the $\mathrm{H}_{2} \mathrm{O}_{2}$ concentration was five times the COD concentration, and the initial $\mathrm{pH}$ value was set to 3 .

From Figure 2, it can be seen that the best $\mathrm{Fe}^{2+} / \mathrm{H}_{2} \mathrm{O}_{2}$ ratio is $9 \% \mathrm{w} / \mathrm{w}$, with a COD removal efficiency of $75.81 \%$. An increase in the $\mathrm{Fe}^{2+}$ in the reaction may shift the equilibrium to side products that increase the generation of hydroxyl radicals and the organic molecule (RH) oxidation rate, as expressed in Equation 2 (Gümüs and Akbal, 2016)

$$
\mathrm{RH}+2 \mathrm{OH} \rightleftharpoons \mathrm{ROH}+\mathrm{H}_{2} \mathrm{O}
$$

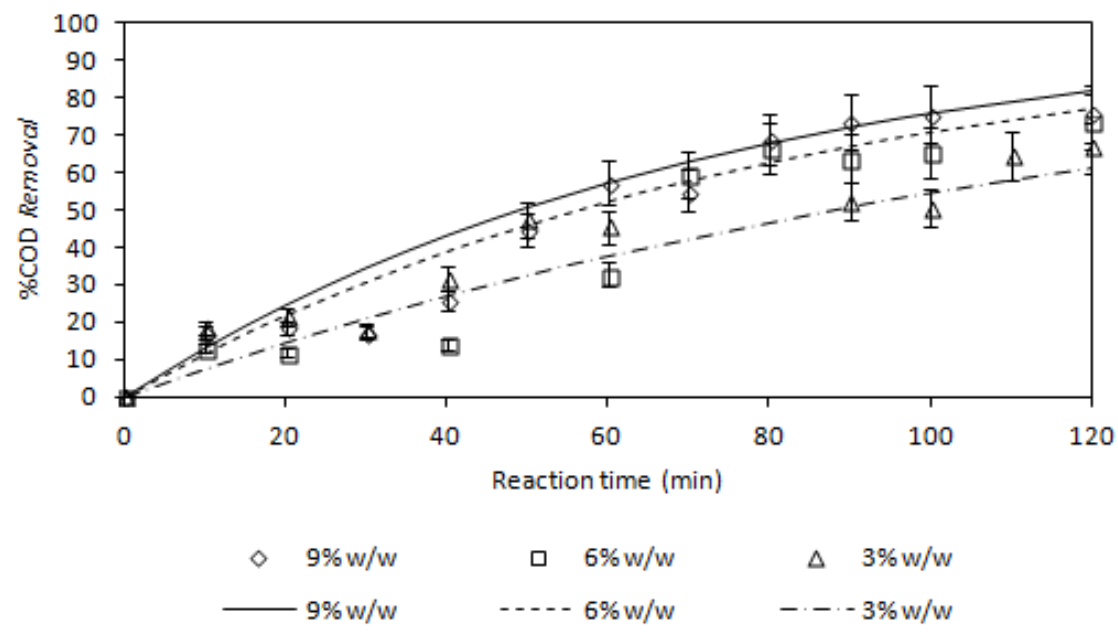

Figure $2 \mathrm{COD}$ removal efficiency at various $\mathrm{Fe}^{2+} / \mathrm{H}_{2} \mathrm{O}_{2}$ ratios

$\square, \circ, \Delta$ indicate experiment data; - - ---,-- indicate model development 


\subsubsection{Effect of $\mathrm{H}_{2} \mathrm{O}_{2}$ concentration on COD removal efficiency}

$\mathrm{H}_{2} \mathrm{O}_{2}$ acts as the main component in Fenton's reagent, producing hydroxyl radicals, which is the main oxidizing agent degrading organic molecules in the PCP wastewater. Various $\mathrm{H}_{2} \mathrm{O}_{2}$ concentrations, the optimal $\mathrm{Fe}^{2+} / \mathrm{H}_{2} \mathrm{O}_{2}$ ratio $(9 \% \mathrm{w} / \mathrm{w})$, and an initial $\mathrm{pH}$ value of 3 were used to investigate the effect of $\mathrm{H}_{2} \mathrm{O}_{2}$ concentration.

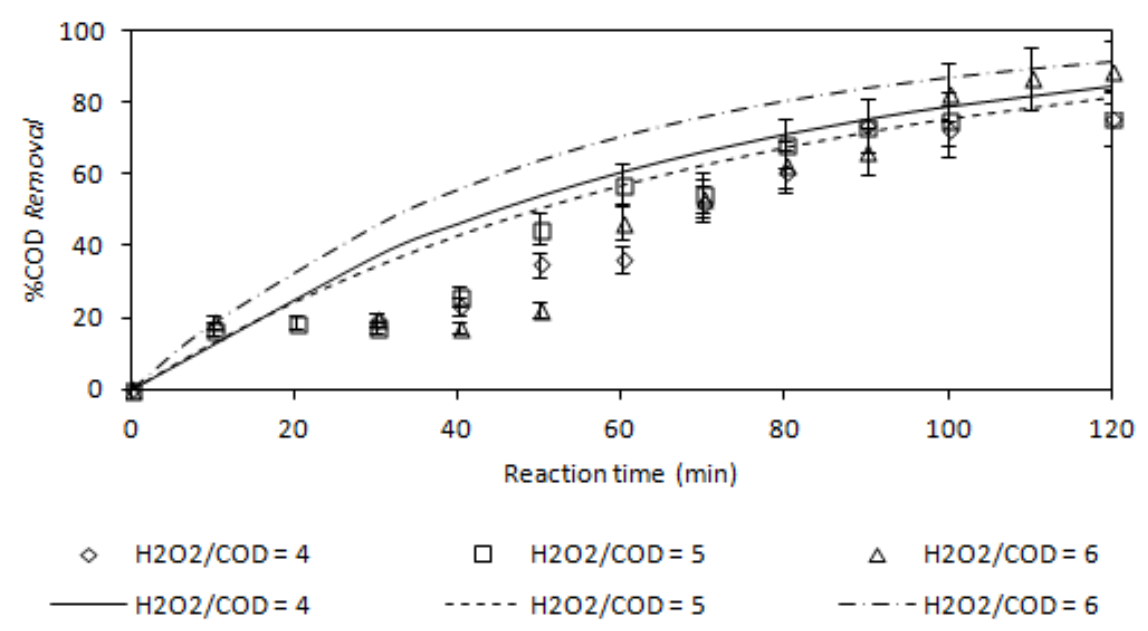

Figure 3 COD removal efficiency at various $\mathrm{H}_{2} \mathrm{O}_{2}$ concentrations

๑, $\bigcirc, \Delta$ indicate experiment data; - - ---,--- indicate model development

From Figure 3, it can be seen that the optimal $\mathrm{H}_{2} \mathrm{O}_{2}$ concentration is six times the initial COD concentration, with a COD removal efficiency of $88.59 \%$. The results show that the optimal value for $\mathrm{H}_{2} \mathrm{O}_{2}$ concentration is $6,324 \mathrm{ppm}$ when the initial COD concentration is $1,054 \mathrm{ppm}$. An increase in the initial $\mathrm{H}_{2} \mathrm{O}_{2}$ concentration increases the production of hydroxyl radicals, thus speeding up the reaction. This follows pseudo-first-order kinetics, in which the $\mathrm{H}_{2} \mathrm{O}_{2}$ concentration is assumed to be constant because of its excess concentration, which can be expressed as Equation 3 (Levenspiel, 1999).

$$
r=K[C O D] \text {, where } \mathrm{K}=k\left[\mathrm{H}_{2} \mathrm{O}_{2}\right]
$$

[COD] and $\left[\mathrm{H}_{2} \mathrm{O}_{2}\right]$ denote the $\mathrm{COD}$ and $\mathrm{H}_{2} \mathrm{O}_{2}$ concentrations, respectively, and $k$ represents the reaction constant. The equation shows that an increase in the $\mathrm{H}_{2} \mathrm{O}_{2}$ concentration will also increase the rate of the reaction, which will increase the COD removal efficiency. Equation 3 will be explained in more detail in the subsection on kinetics analysis.

\subsubsection{Effect of the $\mathrm{pH}$ system on COD removal efficiency}

The $\mathrm{pH}$ system needs to be adjusted because $\mathrm{Fe}^{2+}$ precipitates at a higher $\mathrm{pH}$ than $\mathrm{Fe}(\mathrm{OH})_{2}$. To investigate the effect of $\mathrm{pH}$, various initial $\mathrm{pH}$ system values of 2,3 , and 4 were set, with an $\mathrm{Fe} 2+/ \mathrm{H}_{2} \mathrm{O}_{2}$ ration of $9 \% \mathrm{w} / \mathrm{w}$, and $\mathrm{H}_{2} \mathrm{O}_{2}$ concentration that was six times the COD concentration.

From Figure 4, it can be seen that the optimal initial pH system value is 3, with a COD removal efficiency of $88.59 \%$. At higher $\mathrm{pH}$ values ( $>3$ ), the production of hydroxyl radicals decreases due to equilibrium shifts to the left side, as stated in Equation 1. Furthermore, at higher $\mathrm{pH}$ values $(>3)$, the $\mathrm{H}_{2} \mathrm{O}_{2}$ decomposes into $\mathrm{O}_{2}$ and $\mathrm{H}_{2} \mathrm{O}$, leading to a reduction in oxidation efficiency. Moreover, $\mathrm{Fe}^{2+}$ solubility decreases at higher $\mathrm{pH}$ values, which reduces the ability of the catalyst to generate hydroxyl radicals. As expressed in Equation 4, $\mathrm{Fe}^{2+}$ ions are oxidized to $\mathrm{Fe}^{3+}$ and reduce the production of hydroxyl radicals at low $\mathrm{pH}(\mathrm{pH}<3)$, which reduces the rate of COD degradation.

$$
2 \mathrm{Fe}^{2+}+2 \mathrm{H}^{+} \rightleftharpoons 2 \mathrm{Fe}^{3+}+\mathrm{H}_{2}
$$




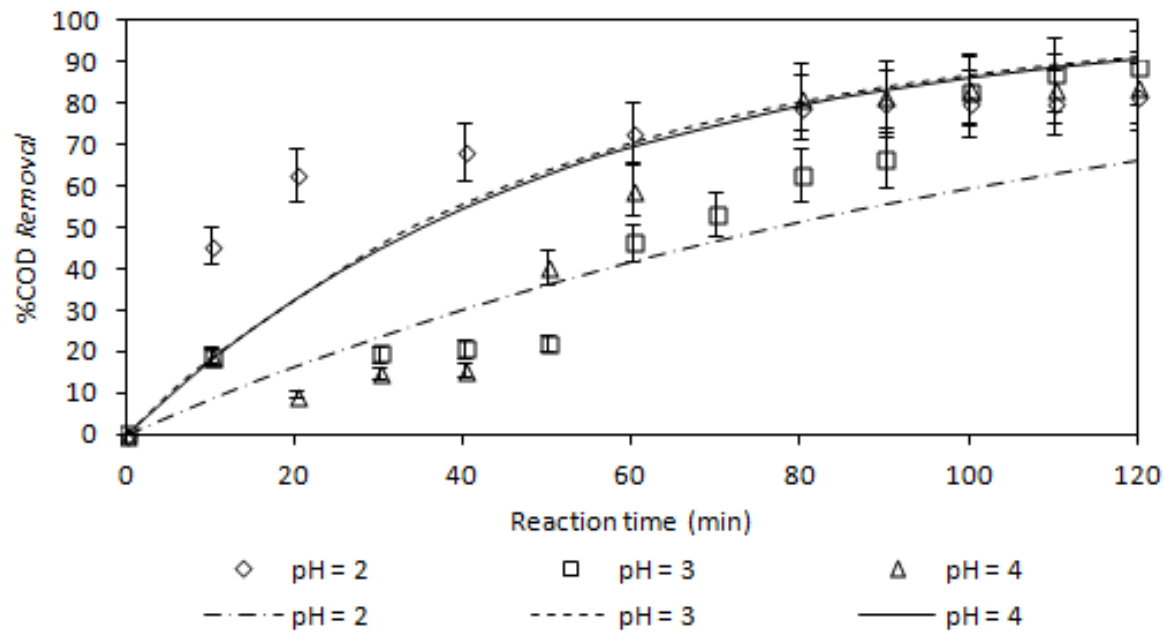

Figure 4 COD removal efficiency at various initial $\mathrm{pH}$ values

$\square, \mathrm{O}, \Delta$ indicate experiment data; - - ---,-- indicate model development

\subsection{Kinetics Analysis of COD Removal}

Kinetics analysis was performed by measuring the COD concentration at time intervals of two hours to determine the overall kinetic model. We used the data on optimal conditions (Figure 4): an $\mathrm{Fe}^{2+} / \mathrm{H}_{2} \mathrm{O}_{2}$ ratio of $9 \% \mathrm{w} / \mathrm{w}$, an $\mathrm{H}_{2} \mathrm{O}_{2}$ concentration of six times the COD concentration, and a pH value of 3.0. Four models are presented in Table 2 . The results show that the degradation of COD tends to follow pseudo-first-order reaction kinetics, as demonstrated by the highest correlation coefficient (the $\mathrm{R}^{2}$ value is close to 1 ).

Table 2 Results from plotting the data sample at optimal conditions in four different kinetic models

\begin{tabular}{|c|c|c|}
\hline Kinetic Models & Formula & Plot \\
\hline $0^{\text {th }}$ order COD & [COD] vs t & $\begin{array}{c}y=-8.27 x+1054.4 \\
\mathrm{R}^{2}=0.91\end{array}$ \\
\hline $\begin{array}{l}1^{\text {st }} \text { order COD (pseudo-first-order } \\
\text { kinetics) with constant }\left[\mathrm{H}_{2} \mathrm{O}_{2}\right]\end{array}$ & $\ln [\mathrm{COD}]$ vs $t$ & $\begin{array}{c}y=-0.021 x+7.38 \\
\mathrm{R}^{2}=0.92\end{array}$ \\
\hline $2^{\text {nd }}$ order COD & $\frac{1}{[C O D]} \mathrm{vs} \mathrm{t}$ & $\begin{array}{c}y=7 \times 10^{-5} x-0.0013 \\
\mathrm{R}^{2}=0.81\end{array}$ \\
\hline $1^{\text {st }}$ order $\mathrm{COD}$ and $\mathrm{H}_{2} \mathrm{O}_{2}$ & $-\ln \frac{[\mathrm{COD}]}{\left[\mathrm{H}_{2} \mathrm{O}_{2}\right]} \mathrm{vs} \mathrm{t}$ & $\begin{array}{c}y=0.081 x+0.73 \\
\mathrm{R}^{2}=0.87\end{array}$ \\
\hline
\end{tabular}

Table $3 \mathrm{COD}$ concentration and $\mathrm{H}_{2} \mathrm{O}_{2}$ concentration as a function of reaction time

\begin{tabular}{ccc}
\hline $\mathrm{t}(\mathrm{min})$ & {$[\mathrm{COD}](\mathrm{ppm})$} & {$\left[\mathrm{H}_{2} \mathrm{O}_{2}\right](\mathrm{ppm})$} \\
\hline 0 & 1054.00 & 6324.00 \\
10 & 855.90 & 2323.53 \\
30 & 847.82 & 2213.24 \\
40 & 823.57 & 1992.65 \\
50 & 820.88 & 1882.35 \\
60 & 489.44 & 1772.06 \\
70 & 381.66 & 1735.29 \\
80 & 354.71 & 1477.94 \\
90 & 303.51 & 1110.29 \\
100 & 179.56 & 816.18 \\
110 & 136.45 & 742.65 \\
120 & 120.28 & 669.12 \\
\hline
\end{tabular}




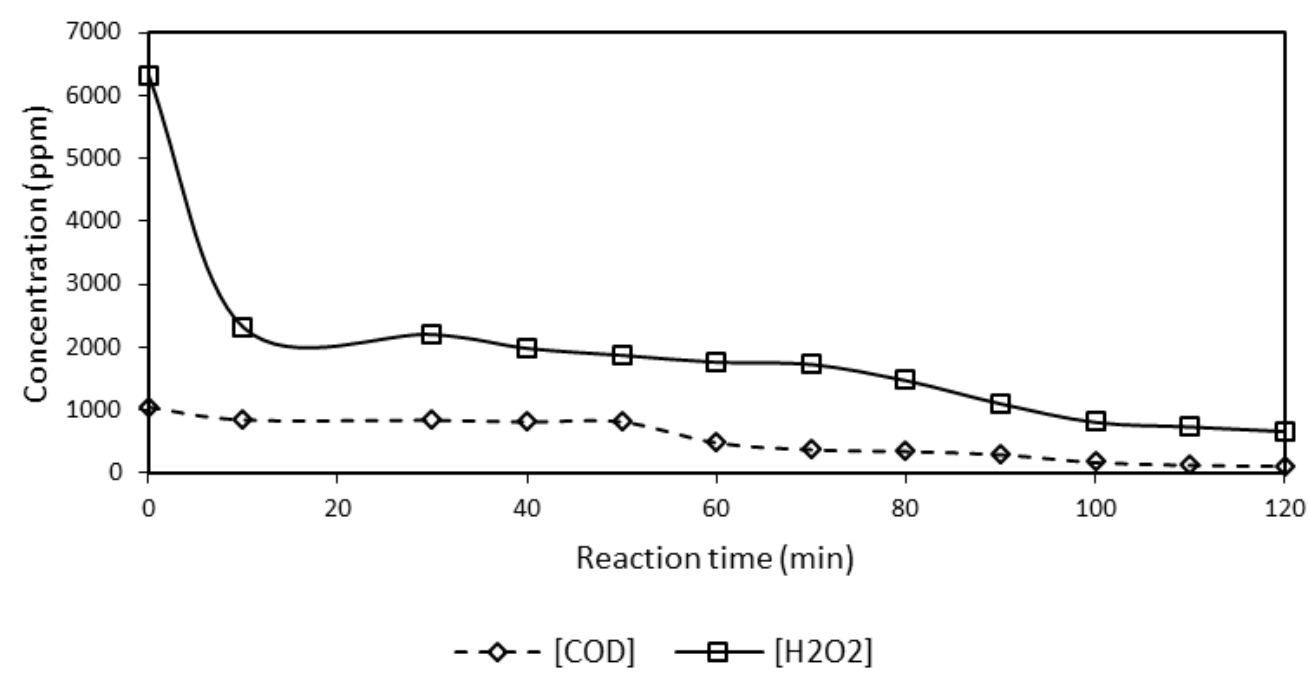

Figure $5 \mathrm{COD}$ concentration and $\mathrm{H}_{2} \mathrm{O}_{2}$ concentration as a function of reaction time

From Table 3 and Figure 5, it can be seen that the $\mathrm{H}_{2} \mathrm{O}_{2}$ concentration during the experiments was always in excess, which proved the assumption of a constant $\mathrm{H}_{2} \mathrm{O}_{2}$ concentration and the validity of the pseudo-first-order reaction kinetics presented in Equation 3. Equation 3 expresses the pseudo-first-order reaction kinetics and implies that an increase in the $\mathrm{H}_{2} \mathrm{O}_{2}$ concentration increases the effectiveness of the COD removal. It proves that the $\mathrm{H}_{2} \mathrm{O}_{2}$ concentration used in this experiment (six times the COD concentration) is the most effective for COD degradation. Based on the data presented in Table 2 and Table 3, we calculated the constant rate of reaction $(\mathrm{K})$, which was found to be $0.021 \mathrm{~min}^{-1}$. This rate constant is lower than the reaction rate constant derived in a previous study on Fenton's oxidation in dye wastewater (Gunawan et al., 2017).

\subsubsection{Profile of COD concentration versus time in pseudo-first-order reaction kinetics}

Based on the kinetic model and the rate of reaction, the COD concentration for a reaction time interval can be obtained using Equation 5 (Levenspiel, 1999)

$$
[C O D]=[C O D] 0 \times e^{-K t}
$$

where [COD] is the COD concentration at a specific time, [COD]o is the initial COD concentration $(1,054 \mathrm{ppm}), K$ is the reaction rate constant $\left(0.021 \mathrm{~min}^{-1}\right)$, and $t$ is the duration of the reaction in minutes. Then, we plotted the COD concentration as a function of time, based on Equation 5. The result is presented in Table 4 and Figure 6.

From Table 4 and Figure 6, it can be seen that at least 100 mins of wastewater treatment was required to achieve a COD concentration of less than $150 \mathrm{ppm}$, which meets the discharge standard requirement for a pharmaceutical factory. However, the COD concentration requirement for treated wastewater to be discharged into a first-class river is a COD concentration value of less than $100 \mathrm{ppm}$, as stated in the regulations of the East Java regional Province (No. 72, year 2013). Hence, a minimum reaction time of 130 mins is required to meet the regulation requirements (Table 4 and Figure 6). The COD removal efficiency was $93.04 \%$, which is slightly less than the results of a previous study that used photocatalytic degradation (Khraisheh et al., 2013).

\subsubsection{Application in continuous systems and reactor volume calculations}

The residence time of PCP wastewater in a PFR is equal to the reaction time required in a batch system because the residence time in a PFR is uniform. The residence time is used to determine the required optimal value in reactor design. 
Table 4 COD concentration calculated using the kinetic model equation at optimal conditions

\begin{tabular}{ccc}
\hline $\mathrm{t}(\mathrm{min})$ & {$[\mathrm{COD}](\mathrm{ppm})$} & \%COD removal \\
\hline 0 & 1054.00 & 0 \\
10 & 858.64 & 18.54 \\
20 & 699.49 & 33.64 \\
30 & 569.84 & 45.94 \\
40 & 464.22 & 55.96 \\
50 & 378.17 & 64.12 \\
60 & 308.08 & 70.77 \\
70 & 250.97 & 76.19 \\
80 & 204.46 & 80.60 \\
90 & 166.56 & 84.20 \\
100 & 135.69 & 87.13 \\
110 & 110.54 & 89.51 \\
120 & 90.05 & 91.46 \\
130 & 73.36 & 93.04 \\
140 & 59.76 & 94.33 \\
150 & 48.68 & 95.38 \\
\hline
\end{tabular}

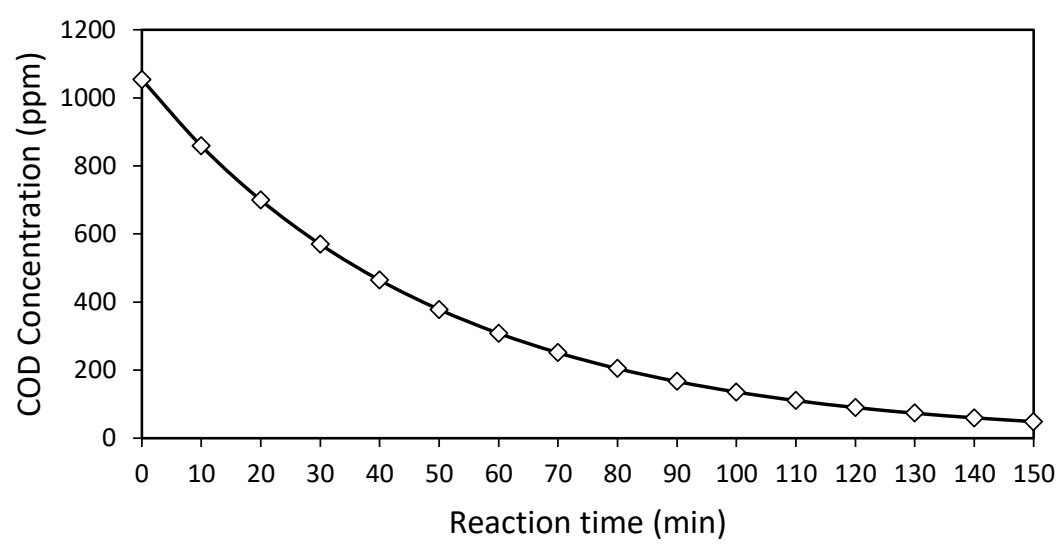

Figure 6 COD concentration with kinetic model equation at optimal conditions vs. reaction time

It has been shown that the reaction time required to achieve 93.04\% COD removal efficiency in a batch reactor is 130 mins, which is used as the residence time. Based on the reaction time in batch mode, we calculate the PFR volume for comparison with the batch system volume. As the wastewater flow rate in the factory is $15 \mathrm{~m}^{3}$ per day, and assuming a $20 \%$ safety factor for scale-up, we can calculate the volume needed in a PFR using Equation 6.

$$
V_{\text {reactor }}=\tau \times v
$$

where $V_{\text {reactor }}$ is the reactor volume, $\tau$ is the residence time, and $v$ is the flow rate. For the given flow rate of $15 \mathrm{~m}^{3}$ per day, the reactor volume required for a PFR is $1.625 \mathrm{~m}^{3}$. If a batch reactor is employed, we need to estimate the total preparation and cleaning time, which is assumed to be 50 mins. Therefore, the total time for each batch process is 180 mins, which gives eight batches of operation a day. Using the same flow rate and a $20 \%$ safety factor for scale-up, the reactor volume of the batch reactor would be $2.25 \mathrm{~m}^{3}$. It can be concluded that for the same amount of wastewater, the reactor volume required for a PFR is less than that required for a batch reactor, which means that a continuous system (using a PFR) is more advantageous in terms of size and cost. 
There are some advantages to using a PFR over batch reactors and MFRs, which are: the wastewater and $\mathrm{H}_{2} \mathrm{O}_{2}$ concentration in the outlet can be kept constant, and consequently, the reactor is controlled more easily in a PFR than in the batch system; compared to an MFR, side reactions such as scavenging hydroxyl radicals can be minimized because the pattern of wastewater and $\mathrm{H}_{2} \mathrm{O}_{2}$ concentration in a PFR is similar to that in a batch reactor; the operation cost is cheaper because it is an efficient process, the reactor cleaning time is less, and a smaller reactor size is required.

\subsection{Operation Cost Analysis}

In this study, the operation cost is calculated at optimal conditions: the $\mathrm{Fe}^{2+} / \mathrm{H}_{2} \mathrm{O}_{2}$ ratio was $9 \% \mathrm{w} / \mathrm{w}$, the $\mathrm{H}_{2} \mathrm{O}_{2}$ concentration was six times the COD concentration, and the initial $\mathrm{pH}$ value was 3 . The operation cost was calculated based on a batch system operation time of two hours, and the total working volume of wastewater treated was $750 \mathrm{~mL}^{\mathrm{H}} \mathrm{H}_{2} \mathrm{SO}_{4}$ was used to adjust the initial $\mathrm{pH}$ value, $\mathrm{H}_{2} \mathrm{O}_{2}$ was used to produce hydroxyl radicals, $\mathrm{FeSO}_{4} .7 \mathrm{H}_{2} \mathrm{O}$ was used as the $\mathrm{Fe}^{2+}$ catalyst source, and $\mathrm{NaOH}$ of $2 \mathrm{moL} / \mathrm{L}$ was used to neutralize and stop the reaction process. The total cost of chemicals used is IDR 826 for an operation time of two hours. The chemicals used and the operation costs are presented in Table 5.

Table 5 Chemical cost of materials used in the experiments

\begin{tabular}{cccc}
\hline Item & Quantity & Cost/unit (IDR/unit) & Cost (IDR) \\
\hline $\mathrm{H}_{2} \mathrm{SO}_{4} 96 \%$ & $1 \mathrm{~mL}$ & 126.72 & 126.72 \\
$\mathrm{H}_{2} \mathrm{O}_{2} 30 \%$ & $16.8 \mathrm{~mL}$ & 39 & 655.20 \\
$\mathrm{FeSO}_{4} 7 \mathrm{H}_{2} \mathrm{O}$ & $2.26 \mathrm{~g}$ & 1.3 & 2.94 \\
$\mathrm{NaOH} 2 \mathrm{M}^{5}$ & $6.4 \mathrm{~g}$ & 6.5 & 41.60 \\
\hline \multicolumn{5}{c}{ TOTAL } & 826.46 \\
\hline
\end{tabular}

The electricity required for the stirrer is $72 \mathrm{~W}$, which is equal to $0.144 \mathrm{kWh}$ for an operation time of two hours. Based on the electricity tariff from the Indonesia Power Plant for October 2018, electricity cost is IDR 1,467.28 per kWh. Thus, the cost of the electricity required is IDR 211.28 .

The total operational cost, including chemicals and electricity required for treating 750 $\mathrm{mL}$ of wastewater, was IDR 1,038. Therefore, total operational cost for PCP industrial wastewater treatment using Fenton's method in a batch system is estimated to be IDR 1,385 per liter.

\section{Conclusions}

Fenton's process is effective for the treatment of PCP industrial wastewater. The experimental results show that Fenton's treatment is feasible for the reduction of COD in PCP wastewater. The COD removal efficiency for PCP industrial wastewater is influenced by the $\mathrm{Fe}^{2+} / \mathrm{H}_{2} \mathrm{O}_{2}$ ratio, the $\mathrm{H}_{2} \mathrm{O}_{2}$ concentration, and the $\mathrm{pH}$ value. The optimal parameters used in this experiment are a $\mathrm{H}_{2} \mathrm{O}_{2}$ concentration of six times the COD concentration, an $\mathrm{Fe}^{2+} / \mathrm{H}_{2} \mathrm{O}_{2}$ ratio of $9 \% \mathrm{w} / \mathrm{w}$, and an initial $\mathrm{pH}$ value of 3 . The initial and final COD concentrations were 1,054 ppm and $120.28 \mathrm{ppm}$, respectively, for a 120 -min reaction time, with $88.59 \%$ COD removal. The kinetic model follows pseudo-first-order reaction kinetics, as demonstrated by a high correlation coefficient $\left(\mathrm{R}^{2}\right)$ with a reaction rate constant of $0.021 \mathrm{~min}^{-1}$. Based on that model, the COD removal efficiency is $93.04 \%$ after a 130-min reaction time, with an outlet COD concentration of $73.36 \mathrm{ppm}$, which is less than $100 \mathrm{ppm}$ and meets the discharge standard requirements. Regarding reactor volume, the reactor size required for a PFR is $27.78 \%$ less than that required for a batch 
reactor for a 130 min reaction time. The operating cost to treat PCP wastewater in a batch system is IDR 1,385 per liter of wastewater. Future research may develop the optimal performance of a PFR by studying the flow rate parameter and conducting a kinetic study of the intermediate compound. The oxidation can be carried out by dosing the PCP wastewater with $\mathrm{H}_{2} \mathrm{O}_{2}$ and $\mathrm{FeSO}_{4} .7 \mathrm{H}_{2} \mathrm{O}$ in a tubular reactor.

\section{Acknowledgements}

The authors would like to acknowledge funding support from VP Industry via Grant 105/VP-01/2018.

\section{References}

American Public Health Association (APHA), 1991. Standard Methods for the Examination of Water and Wastewater. 20th Edition. American Public Health Association Press, Washington, DC, USA

Archer, E., Petrie, B., Kasprzyk-Hordern, B., Wolfaardt, G.M., 2017. The Fate of Pharmaceuticals and Personal Care Products (PPCPS), Endocrine Disrupting Contaminants (EDCS), Metabolites and Illicit Drugs in a WWTW and Environmental Waters. Chemosphere, Volume 174, pp. 437-446

Babuponnusami, A., Muthukumar, K., 2014. Review on Fenton and Improvements to the Fenton Process for Wastewater Treatment. Journal of Environmental Chemical Engineering, Volume 2(1), pp. 557-572

Gümüs, D., Akbal, F., 2016. Comparison of Fenton and Electro-Fenton Processes of Oxidation of Phenol. Process Safety and Environmental Protection, Volume 103(Part A), pp. 252258

Gunawan, D., Kuswadi, V.B., Sapei, L., Riadi, L., 2017. Yarn Dyed Wastewater Treatment using Hybrid Electrocoagulation-Fenton Method in Continuous System: Technical and Economical Viewpoint. Environmental Engineering Research. Volume 23(1), pp. 114119

Huckaba, C.E., Keyes, F.G., 1948. The Accuracy of Estimation of Hydrogen Peroxide by Potassium Permanganate Titration. Journal of the American Chemical Society, Volume 70(4), pp. 1640-1644

Kanhaiya, L., Anurag, G., 2017. Utilization of Dissolved Iron as Catalyst during Fenton-like Oxidation of Pretreated Pulping Effluent. Elsevier, Volume 111, pp. 766-774

Karamah, E.F., Anindita, L., Amelia, D., Kusrini, E., Bismo, S., 2019. Tofu Industrial Wastewater Treatment with Ozonation and the Adsorption Method using Natural Zeolite. International Journal of Technology, Volume 10(8), pp. 1498-1504

Khraisheh, M., Kim, J., Campos, L., Al-Muhtaseb, A.H., Al-Hawari, A., Ghouti, M.A., Walker, G.M., 2013. Removal of Pharmaceutical and Personal Care Products (PPCPs) Pollutants from Water by Novel $\mathrm{TiO}_{2}$-Coconut Shell Powder (TCNSP) Composite. Journal of Industrial and Engineering Chemistry, Volume 20(3), pp. 979-987

Levenspiel, 0., 1999. Chemical Reaction Engineering, 3rd Edition. John Wiley \& Sons, Inc., New York, NY, USA

Lin, Y.L., Li, B.K., 2015. Removal of Pharmaceuticals and Personal Care Products by Eichhornia crassipe and Pistia stratiotes. Journal of the Taiwan Institute of Chemical Engineers, Volume 58, pp. 318-323

Munoz, M., Garcia-Muñoz, P., Pliego, G., de Pedro, Z.M., Zazo, J.A., Casas, J.A., Rodriguez, J.J., 2016. Application of Intensified Fenton Oxidation to the Treatment of Hospital 
Wastewater: Kinetics, Ecotoxicity and Disinfection. Journal of Environmental Chemical Engineering, Volume 4(4, Part A), pp. 4107-4112

Narumiya, M., Nakada, N., Yamashita, N., Tanaka, H., 2013. Phase Distribution and Removal of Pharmaceuticals and Personal Care Products During Anaerobic Sludge Digestion. Journal of Hazardous Materials, Volume 260, pp. 305-312

Park, J.H., Wang, J.J., Xiao, R., Tafti, N., DeLaune, R.D., Seo, D.C., 2017. Degradation of Orange $\mathrm{G}$ by Fenton-like Reaction with Fe-impregnated Biochar Catalyst. Bioresource Technology, Volume 249, pp. 368-376

Pignatello, J.J., Oliveros, E., Mackay, A., 2006. Advanced Oxidation Processes for Organic Contaminant Destruction based on the Fenton Reaction and Related Chemistry. Critical Reviews in Environmental Science and Technology, Volume 36(1), pp. 1-84

Saksono, N., Seratri, R.T., Muthia, R., Bismo, S., 2015. Phenol Degradation in Wastewater with a Contact Glow Discharge Electrolysis Reactor using a Sodium Sulfate. International Journal of Technology, Volume 6(7), pp. 1153-1163

Sharfan, N., Shobri, A., Anindria, F.A., Mauricio, R., Tafsili, M.A.B., Slamet, 2018. Treatment of Batik Industry Waste with a Combination of Electrocoagulation and Photocatalysis. International Journal of Technology, Volume 9(5), pp. 936-943

Suanon, F., Sun, Q., Li, M., Cai, X., Zhang, Y., Yan, Y., Yu, C.P., 2017. Application of Nanoscale Zero Valent Iron and Iron Powder During Sludge Anaerobic Digestion: Impact on Methane Yield and Pharmaceutical and Personal Care Products Degradation. Journal of Hazardous Materials, Volume 321, pp. 47-53 